Alma Mater Studiorum - Università di Bologna DEPARTMENT OF ECONOMICS

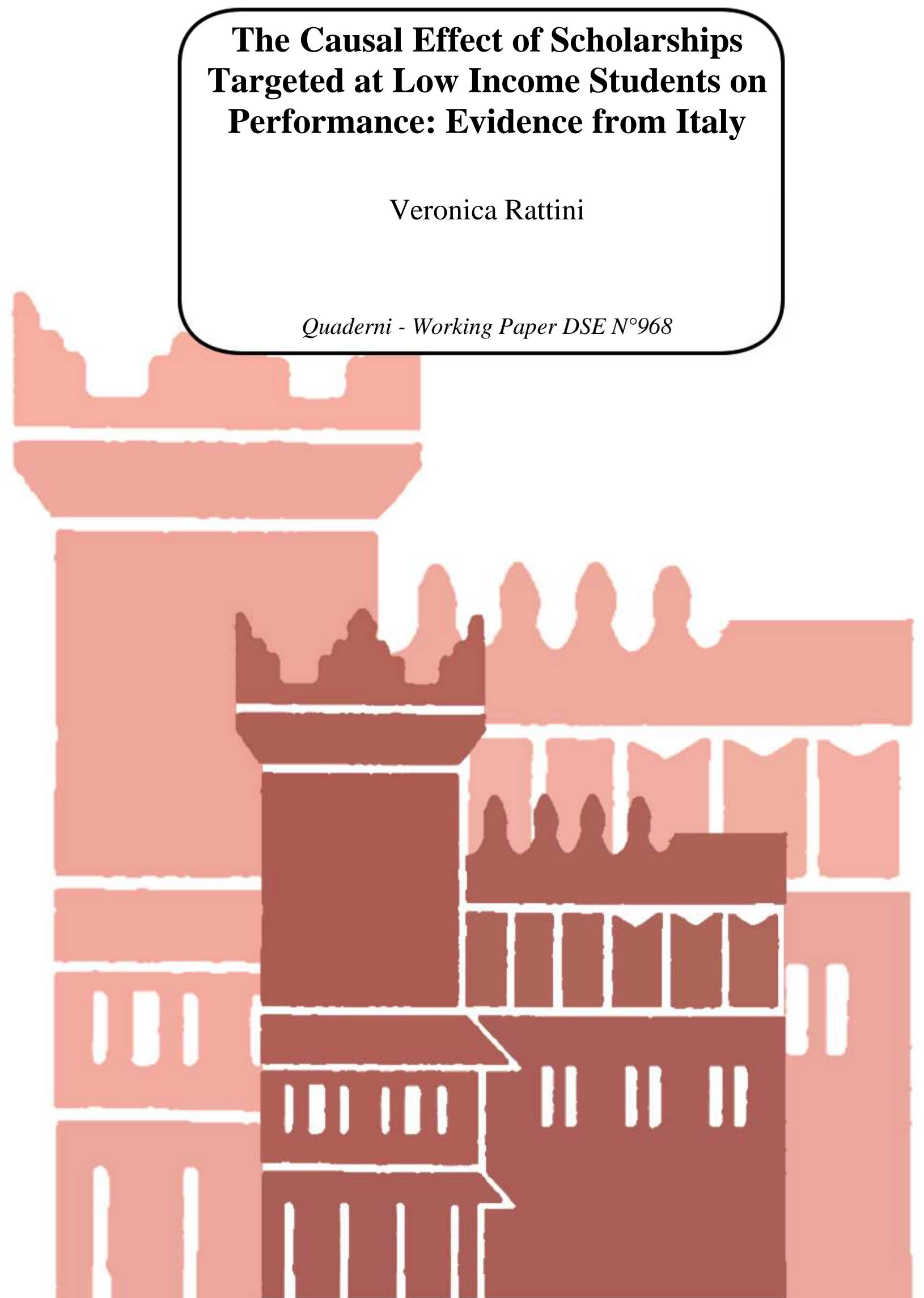




\title{
The Causal Effect of Scholarships Targeted at Low Income Students on Performance: Evidence from Italy
}

\author{
Veronica Rattini*
}

\begin{abstract}
This paper exploits discontinuities in the assigment of scholarships targeted at low income students in an Italian University in order to evaluate the effects of monetary incentives on students' academic achievement. Results reveal positive and sizeable causal effects both in terms of credits and grades. Gender differentials also emerge: male students drive the results on credits outcome while females students drive the effect on grades. These results suggest that the scholarship design contributes to reducing the probability of delayed graduation ("Fuori Corso" problem).
\end{abstract}

JEL codes: H5, I21, I28, .

Keywords: Human Capital, Monetary Incentives, Regression Discontinuity

${ }^{*}$ Contact author: veronica.rattini2@unibo.it 


\section{Introduction}

Given the extensive social and private benefits that result from tertiary education, inclusive access and a well functioning system are essential for achieving social justice and enhancing national human capital. Furthermore, if one considers the strong correlation between tertiary education enrollment and family background (McPherson and Schapiro, 2006), concrete and effective initiatives are necessary to provide better opportunities of access and success for students from lower income families and minority groups.

In Italy, the "Right to Study" Constitutional principle responds to such equity purposes by providing different types of services for students from lower income family who want to enroll at an university program. In this research, I focus on the "Right to Study Scholarship". In particular, I analyze how the monetary provision of such scholarship causally impact on students' academic achievements by applying a Regression Discontinuity analysis.

I interested in understanding whether these monetary incentives could serve to boost students' performance by reducing direct and indirect college costs. Moreover, since the maintenance and non-reimbursement of the mean-tested scholarship are conditional on the achievement of minimum credit requirements, the analysis gives the opportunity to understand whether such requirements are adequately defined in order to serve the purpose of enhancing students' performance and the extent to which they could alleviate the problem of being "Fuori Corso" (delayed graduation), which is a wide-spread phenomenon in many countries (see, among others, Hakkinen and Usitalo, 2002; Van Ours and Ridder, 2002; Brunello and Winter-Ebmer, 2003; Bowen, Chingos and McPherson, 2009).

In the economic literature, a growing number of empirical studies addresses the question of how monetary incentives shape students' educational choices. In particular, a number of papers investigate the effect of such incentives on the choice of school program and on degree completion (Hansen 1983; Kane 1994; Dynarski 2000,2003; Van der Klaauw 2002; Goodman 2008). Other works, mostly from US, have focused on the effects on academic performance and do not find univocal results (Angrist and Levy 2002; Leuven et al. 2003; Cornwell at al. 2003; Dynarski 2005; 
Belot et al. 2007; Angrist et al. 2009).

For what concerns the case of Italy, the evidence is not uniform and the present study ought to provide new insights on the issue. In particular, Garibaldi et al. (2012) find that an increase in college cost, in response to delayed graduation, exerts a remarkable effect on the on-time completion rate, using evidence from Bocconi University. In line with this evidence, I find that monetary incentives speed up the number of credits a student achieves in the first year of the degree without prejudice to, but actually increasing, average grades. This effect can arguably help the "Fuori Corso" problem. In other words, the need-based scholarship leads low-income students to exert more efforts in order to meet minimum credit requirements and to avoid losing their grants (which is equivalent to an increase in university costs).

De Paola et. al (2010) find that "financial rewards increase student performance both in terms of number of credits acquired and grades obtained at exams". My results are in line with such evidence, even if their institutional context is different with respect the one analyzed here. In fact, they analyzed the effect of an extra reward financed through the European Social Found for above-average students, which could not give the same incentives as the Right to Study Scholarship.

Mealli and Rampichini (2012) have, instead, analyzed data regarding four Italian universities and they show that the "Right to Study Scholarship" (which is the same Italian institution that we here analyze) prevents students from droping-out. However, they find that the effect vanishes for lower income students. Here we provide new evidence from the "Right to Study Scholarship" at the University of Bologna showing that such effects on performance for lower income students are not only significant but are also remarkably large.

My results are also at odds with Schizzerotto et al. (2012) who studies the effect of a meritbased scholarship at the University of Trento and do not find any significant effect on academic achievement. Such contrast might have to do with the fact that they use a relatively small sample from survey data, which are more sensible to measurement errors. In my case, the administrative dataset I use allows to gain precision on the estimates. 
The paper is organized as follow. The next section outlines how the present study relates to the literature developed so far. Section 3 analyzes the institutional framework and Section 4 describes the data and methodology. In section 5, I will present and discuss results on the causal effects of scholarships on different measures of academic achievement. Section 6 discusses the robustness of the findings and Section 7 concludes.

\section{Literature Review}

In recent years a growing number of interventions designed to increase tertiary education enrolment, completion and effectiveness took place. A number of these programs targeted low income students. While most of the interventions are based on monetary incentives, program design fairly varies. Examples of the designs are: merit and need-based scholarships, tuition subsidies or parttime working programs.

Such policies are justified by the fact that large economic returns related to tertiary education have been clearly documented and they do not constitute only private benefits (Barro 1991, Acemoglu, D., and J. Angrist 1999, Temple 2000, Dasgputa 2001, Glaeser et al. 2004). Positive externalities resulting from education provide a strong economic reasoning for such interventions. Moreover, it has been shown that the effort provided by students in schooling activities is one of the most important factors in the human capital accumulation, possibly more effective than teacher quality and school resources (Costrell, 1994; Bonesronning, 2004).

Further justifications come from the fact that, in economic theory, monetary aids are supposed to act as incentives promoting effort and scholastic performance (Lazear 2000) being, therefore, helpful in reducing the still nowadays large percentage of young students who face severe problems in educational choice. It is well documented, in fact, that the share of students who drops-out the tertiary education is commonly high even in developed countries and that time to degree completion has increased remarkably in the last two decades. 1 Therefore, the interest in how such

\footnotetext{
${ }^{1}$ For example, Bound et al. (2006) for US and Brunello and Winter-Ebmer (2003) for Europe
} 
aid programs are related to students' performance started to grow in economic research. However, there seems to be much room from further research since results are by no means univocal: some studies provide evidence of a positive impact, while others find rather weak effects. This hints at the necessity of better understanding of how different policy designs implicate in different effects on performance and how these effects vary across different groups of subjects.

In non-experimental research the effectiveness of academic support services is mixed and do not provide a realiable causal measure of such relationship (e.g., surveys by Bailey et al. 2005; Pascarella et al. 1991; Lotkowski et al. 2004, and Wyckoff et al. 1998). On the other hand, better designed studies using experimental and quasi-experimental designs draw a more clear picture.

With reference to the US case, Bettinger (2004) shows that a mean-tested programme of financial assistance exerts a remarkable reduction in the drop-out rate in Ohio University. Dynarski (2005), who analyzed the effect of the Georgia's Helping Outstanding Pupils Educationally (HOPE) meritbased program, finds a positive effect in college completion by 3 to 4 percentage points. Cornwell at al. (2003) analyze the same program and find that the shift from need- to merit-based aid increases the probability to withdraw and reduces the number of average credits obtained. Angrist and Lavy (2009) evaluate the effectiveness of financial rewards on the academic achievement of Israeli students. They find that the program has led to relevant effects for female but not for male. Differences among genders emerge in Angrist, Lang and Oreopoulos (2009), who conduce an experimental evaluation on students enrolled to a large Canadian University. The results, in fact, show that while male students were not affected by the program, female ones improved their academic performance.

For what concerns Europe, Leuven et al. (2003) analyze the effect of merit-based rewards for students enrolled at the University of Amsterdam. They find that only high-ability students and those with highly educated fathers obtain better academic achievement when assigned to the high reward group. For the whole sample taken together instead, there was no effect. Belot et al. (2007) exploit a Dutch reform in the educational system in order to understand the effect of student assistance on academic performance and students' time allocation. They find that there is a small positive effect on the grades but drop-out and time allocation of students remain basically 
unchanged. De Paola et al. (2010) analyze the effect of a randomly assigned merit-reward for students enrolled at University of Calabria. They find positive effects of the monetary incentives on average grades. Garibaldi et al. (2012) find that at Bocconi University in Milan, the increase in the tuition payments for "Fuori Corso" students, i.e their enrollment in the university system extended beyond the legal length of their program, exert a remarkable effect on on-time completion rate.

Mealli and Rampichini (2012) analyze data regarding four Italian universities and show how public provided university scholarships, under the "Right to Study Scholarship", prevent drop-out for those students from medium income families, while for poorer students the effects are not significant. Schizzerotto et al. (2012) looks instead at the incentives assigned to students from low income families introduced in a well-defined area in the North-East of Italy, the administrative province of Trento. They find no effect whatsoever on the drop-out rate, the average mark and the number of credits achieved.

In sum, from a broad review of the recent empirical literature, it becomes clear that the overall evidence on the effect of monetary incentives is rather controversial, ranging from studies finding no effects whatsoever to studies finding large and positive effects on performance.

The goal of this paper is to enrich this debate showing the results of a mean-tested program carried out in the Italian context. In particular, I try to disentangle the pure effect of the so called "Right to Study Scholarship" from other confounding factors on students' academic achievement through applying a Regression Discontinuity Design. The idea underlying the "Right to StudyScholarship" is to reduce the cost related to tertiary education attendance in order to prevent low family income students from being excluded, drop-out, or under-perform with respect to other pupils due to financial constraints. This study show how such institution could be used to serve the additional pourposes of reducing the percentage of "Fuori Corso" students and, more generally, in fostering the accumulation of human capital. 


\section{The Institutional Framework}

Tertiary education in Italy is generally accessible to students with an high school diploma, independently of the type obtained (scientific, classical, professional). Moreover, the Italian Constitution states in art. 34 that University education should be accessible also to those students who do not have the financial resources and the that the Italian Republic furthers the realization of the, so called, "Right to Study" by providing scholarship and other allowances to students.

"Pupils of ability and merit, even if lacking financial resources, have the right to attain the highest grades of studies. The republic furthers the realization of this right by scholarships, allowances to families, and other provisions, to be assigned through competitive examinations."

To enhance equal opportunity and fair access, the region offers many types of services: allowances for international mobility, housing and meals services, services for people with disability, vouchers for education programs (Master, High-level education, etc.), fiduciary loans, and parttime working possibilities. The present study will be focused on the "Right to Study Scholarships" offered for the University of Bologna. The "Right to study Scholarship", from now on "RSS", is one of the services provided by the Region of Emilia-Romagna, where the University of Bologna is located, to promote access and equity in education. In particular this research want to measure what are the effects of such monetary incentives on students' academic achievement.

The "Right to Study" service in Emilia-Romagna has generally a large coverage, both in terms of the number of recipients and of the amount of financial resources provided. Specifically, 13.475 students received a RSS over a total of 98.357 students in the region (13,7\%) for the 2008/2009 academic year. ${ }^{2}$ Furthermore, to finance the RSS for the same academic year, the Region of EmiliaRomagna collected: from national resources $€ 151.986 .000$, from regional resources $€ 158.120 .201$, from regional taxes $€ 171.085 .441$, making a total of $€ 481.191 .642$. $^{3}$

In this perspective, it becomes quite important to know how these grants shape students' incentives and, in particular, whether they have any effects on students' academic achievements,

\footnotetext{
${ }^{2}$ Data from "Ministry of Education, University and Research - MIUR"

${ }^{3}$ Data from "Ministry of Education, University and Research - MIUR"
} 
especially in Italy where students' profiles and performance are quite peculiar. In fact, it has been estimated ${ }^{4}$ that $36 \%$ of students are "Fuori Corso", i.e those whose their enrollment in the university system extended beyond the legal length of their program, and 21,7\% of students dropout. Moreover, the OECD ${ }^{5}$ estimates that in Italy $23,2 \%$ of young in the $15-29$ age bracket are NEET-Not in Education, Employment, or Training and that the employment rates of the youths in 25-29 age bracket is one of the smallest in Europe. In this context, therefore, proper monetary incentive schemes could play a role not only in providing fair access to the University but also in fostering students' performances and enriching national human capital, as through the prevention of university drop-out and the reduction of the share of "Fuori Corso" students.

The regional agency appointed for the distribution of the "Right to Study" services is ER.GO and from 2008 onward, the agency have fully covered all the scholarship' applicants, a 100\% successful rate. The application to scholarships is made before the academic year starts. ${ }^{6}$ Results on allowance eligibility are published within few months and the first installment of the grant (50\% of the yearly allowance) is paid due the end of calendar year. The second half of the financial transfer is bind to the satisfaction of precise credit requirements, which are known ex-ante.

The scholarships differ according to the student status which depends on their place of residence: "In sede", i.e their university's course is in the city of residence or they do not live more than 45 minutes far (by public transport) from the university's center; "Fuori sede", i.e their university's course is more than 90 minutes far (by public transport) away from the city of residence, "Pendolari", i.e their university's course is between 45 and 90 minutes away from the city of residence. There is no distinction, on the other hand, with respect to the level of their degree. Within groups, "In Sede", "Fuori Sede", "Pendolari", scholarships are assigned according to three thresholds on one income indicator of the family, ISEE. Furthermore, eligibility is always conditional on a maximum value of a further wealth indicator of the family, ISPE, which shall not exceed $€ 32.320,64$. The ISEE indicator is given by the annual after-tax income plus the $20 \%$ of family assets, adjusted for the family size by means of an equivalence scale; the ISPE is instead an indicator based just

\footnotetext{
${ }^{4}$ AlmaLaurea - Annual Report on University' Graduates 2013

${ }^{5}$ Education at la glance 2013

${ }^{6}$ At the University of Bologna all the courses start from September/ October to June/July of each year.
} 
on the family assets and it is adjusted for the family size by means of an equivalence scale. The amount of scholarships are the following:

Table 1: Scholarship Value

\begin{tabular}{|c|c|c|c|}
\hline ISEE Threshold & "Fuori Sede" & "Pendolari" & "In Sede" \\
\hline Until $€ 11,927.35$ & $€ 5,073.78$ & $€ 3,043.88$ & $€ 2,255.11$ \\
\hline From $€ 11,927.36$ to $€ 14,909.19$ & $€ 3,942.83$ & $€ 2,420.89$ & $€ 1,828.83$ \\
\hline From $€ 14,909.20$ to $€ 17,891.03$ & $€ 2,811.88$ & $€ 1,796.93$ & $€ 1,402.53$ \\
\hline
\end{tabular}

For the undergraduate freshman, scholarship's assignment is conducted just on the basis of the two economic indicators, ISEE and ISPE. The master freshman, should have obtain, in addition, at least 150 credits in the undergraduate program. On the top of that, the grant maintenance and right not to reimburse the scholarship are conditioned to precise credit requirements. Namely, undergraduate students should obtain 25 credits (out of 60) by the end of the first academic year and master students should obtain 30 credits (out of 60) by the end of the first academic year, independently of their status, "Fuori Sede", "In sede", "Pendolari".

For second year applicants, the assignment is conducted on the basis of the two economic indicators, ISEE and ISPE, and on the basis of the credits obtained in the first year of study. Precisely, in order to be eligible for the scholarships, students should have obtained at least 25 credits in the first year of undergraduate course or 30 credits if enrolled in the first year of a master course. Moreover, in order not to reimburse the grant, recipients should obtain at least 80 credits at the end of the second year of enrolment (both for undergraduate and master program). The same credit requirement ( 80 credits by the end of the second year) is used for the third year application, together with the two economic indicators. In addition, students enrolled to the third year of the undergraduate program should obtain at the end of the academic year 135 credits not to refund ER.GO for the scholarship amount.

On the top of credit requirements, there are also "credits bonus". The design of the RSS offers the possibility to students to use credits bonus, ie. they can add a limited numbers of credit bonus 
Table 2: Credits Requirements by the end of each year

\begin{tabular}{rccc}
\hline Type of course & 1st Year & 2st Year & 3rd Year \\
\hline Undergraduate & 25 & 80 & 135 \\
Master & 30 & 80 & - \\
\hline
\end{tabular}

to the number of actual completed credits, in order to meet the requirements. Specifically, students have the right to use:

a) 5 credits bonus if they asked to satisfy the 2 nd year requirement;

b) 12 credits bonus if they asked to satisfy the 3rd year requirement;

Recipients can take advantage of using current year remaining credit bonus in further years, however these are not cumulative.

\section{Data and Methodology}

The data are provided by the regional agency which is in charge of delivering the RSS, ER.GO, and by the University of Bologna. The advantage to use administrative data is that observations on performance and income status are more precise than survey data, therefore it allows for more precise estimates and decreases the risk of measurement errors biases.

The academic year of reference is the 2008/2009 and the sample includes all the freshman admitted in all the twenty three faculties of the University of Bologna. ${ }^{7}$ The data set includes students enrolled at different levels of Tertiary education: Undergraduate level and Master level. The data set also includes information on students' demographic characterstics and on university-related variables: high-school grade, credits and average mark obtained, university center (Bologna, Forlì, Cesena, Rimini, Ravenna), faculty, graduation course, type of scholarship obtained ("In Sede", "Fuori Sede", Pendolari"), ISEE and ISPE.

\footnotetext{
${ }^{7}$ From academic year 2012/2013 the University of Bologna had change the organisation from 23 faculties to 11 Schools and 33 Departments.
} 
Table 3 in the appendix provides descriptive statistics for the sample of students. About $60 \%$ percent of the students are female. The average age is 21 years old. The geographical distribution is quite symmetric as $37 \%$ of students are coming from the North, $26 \%$ from the Center, $28 \%$ from the South of Italy and 9\% are foreign students. The High School grade in Italy ranges from 60 to 100; the sample mean equals 81.6 points. The high school grade is set to missing for foreign students since I do not have enough information to perfectly convert the foreign scale into the Italian ones.

The average number of credits obtained during the first year of enrollment is around 31 with an average grade of 26. Some data on average grade were missing in the data provided by ER.GO and could not be recovered until the time being. "In Sede" and "Fuori Sede" scholarships' students are quite evenly distributed in the sample.

In order to study the effect of scholarships on students' performances, I use a Regression Discontinuity Design. The RDD has been largely used in economics and behavioral sciences and was firstly introduced by Thistlethwaite and Campbell (1960). The attractiveness of such design is that it allows to identify and estimate treatment effects in a context similar to a formal randomized experiment. In particular, data on random assignment of treatment and control groups are commonly used in medical analysis. In economic research and, precisely, in the evaluation of social programs, the use of random assignment is mostly controversial and remains unusual. Under this perspective, RDD succeeds in establishing soft conditions that allow to identify and estimate treatment effect on observational studies, without relying on parametric evaluation model, often criticized in the literature (for example Lalonde(1986)).

The identification and estimation issues for the RDD were formalized in the work of Hahn, Todd, and van der Klaauw (2001), which describes the minimum set of conditions under which it possible to nonparametrically identify the treatment effect.

It is typically imagined that, for each individual $i$, there exists two potential outcomes: $Z_{i}(1)$ if the unit is exposed to the treatment and $Z_{i}(0)$ if not exposed. The difference $Z_{i}(1)-Z_{i}(0)$ represent the causal effect of the treatment. The real problem of causal inference is that we cannot observe the pair $Z_{i}(0)$ and $Z_{i}(1)$ simultaneously (Holland (1986)). We therefore typically focus on average effects of the treatment, $E\left[Z_{i}(1) \mid Y\right]$ and $E\left[Z_{i}(0) \mid Y\right]$ over (sub-)populations, rather than at 
individual level. The idea of the quasi-experimental RD design is to exploit the discontinuities in the treatment assignment. Precisely, assuming that units close enough to the threshold are similar except for their treatment status, the observed difference in outcomes can be attributed just to the treatment. Formally, consider that all individuals to one side of the a certain threshold, $Y=c$, are exposed to treatment and all those to other side are denied treatment. Therefore, we only observe $E[Z i(1) \mid Y]$ that is the average treatment effect for the treated units and $E[Z i(0) \mid Y]$ for the untreated ones. By the continuity assumption is possible to show that we can estimate the average treatment effect as follow:

$$
A T E=\lim _{\epsilon \rightarrow 0} E\left[Z_{i} \mid Y_{i}=c+\epsilon\right]-E\left[Z_{i} \mid Y_{i}=c-\epsilon\right]=E\left[Z_{i}(1)-Z_{i}(0) \mid Y_{i}=c\right]
$$

In our setting, the set of outcome variables, $Z_{i}$, consists of: number of credits and average mark obtained in the first year on enrolment, a constructed index of performance ${ }^{8}$ and by a binary variable taking values $[0,1]$ if the student have satisfied the credits' requirements. The treatment is a dummy variable taking value 1 if the individual receives the higher scholarship (around $€ 840$ more with respect to the counterfactual) and 0 otherwise; the treatment rule is determined by ISEE's thresholds. For the first threshold, the rule is the following: students with the income indicator, ISEE, lower or equal to $€ 11.927,35$ are assigned to the higher scholarship, while students with ISEE between $€ 11.927,36$ and $€ 14.909,19$ are assigned to the lower one; the difference between the two scholarships is of about $€ 950$. For the second threshold, students with an income between $€ 11.927,36$ and $€ 14.909,19$ receive a scholarship of $€ 730$ higher than the students with ISEE between $€ 14.909,20$ and $€ 17.891,03$. The mean aggregate difference of $€ 840$ is computed giving equal weight to the change at the two thresholds.

In order to aggregate students with ISEE near the two thresholds, $c_{i}=\left(c_{1}, c_{2}\right)$, I constructed a

\footnotetext{
${ }^{8}$ The index is constructed by firstly normalizing the credits and the average obtained between [0;1] and then by computing the weighted average of the two measures, giving two equal weights.
} 
new variable $Y_{i}$ that is define by:

$$
Y_{i}=\left\{\begin{array}{l}
0 \text { if ISEE }=c_{i} \\
+\left(I S E E-c_{i}\right) \text { if } c_{i} \leq I S E E \leq c_{i}+\frac{c_{i+1}-c_{i}}{2} \\
-\left(I S E E-c_{i}\right) \text { if } c_{i}-\frac{c_{i+1}-c_{i}}{2} \leq I S E E \leq c_{i}
\end{array}\right.
$$

Notice that the positive (negative) values of $Y_{i}$ are computed taking just the values of ISEE that are greater (smaller) than the threshold values plus the first half of the consecutive threshold' bracket. In this way we are not confounding the scholarships' incentives of students near the first threshold with those of students near the second threshold, and the ones of students near the second threshold with those near the third threshold.

From the treatment analysis on the two thresholds, I will estimate the Local Average Treatment Effect (LATE). In particular:

$$
Z_{i}=\alpha+F\left(Y_{i}\right)+\gamma D_{i}+\epsilon_{i}
$$

where the $Z_{i}$ s a vector of outcomes variable, $F\left(Y_{i}\right)$ is a polynomial of 4 th degree on the constructed variable defined as $Y_{i}, D_{i}$ is the dummy variable taking value equal to 1 if students are assigned to the higher scholarship. Then it is possible to demonstrate that:

$$
\gamma=E\left[Z \mid Y=0^{+}\right]-E\left[Z \mid Y=0^{-}\right]
$$

is an unbiased estimator of the LATE.

\section{Results}

The results are drawn combining data of students who have a value of ISEE near the first and the second scholarships' thresholds (€11.927,35 and $€ 14.909,19$ respectively). By aggregating those data, the analysis gains in term of precision but we lose information on how the effects of interest vary with the ISEE and with the students' status ("In Sede", Fuori Sede", "Pendolari"). The results are presented in Table 4. 
The local average treatment effects are estimated allowing for different polynomials on the two sides of the aggregated threshold. To check for the robustness of the results, I use four specifications with polynomials of different degrees, from the 1st to the 4th degree. As standars in such methodology, when I increase the order of the polynomial form, I simultaneously enlarge the observational range in order to avoid losing the precision of estimates. More precisely, for the 1st polynomial degree I used a bandwidth of $\pm € 500$ around the aggregate ISEE threshold. For the 2nd degree, I add $€ 350$ obtaining a range of $\pm € 850$ while for the 3rd degree we use those observation lying around $\pm € 1200$ with respect the aggregate threshold. For the 4 th degree we use a bandwidth of $\pm € 1400$, the maximum possible range (half of the distance between the first and second threshold).

As it is shown in table 4 , students who receive an higher scholarship amount, on average $€ 840$ more, have better results on academic achievement during the first year of university enrollment. In particular, according to the specification used, students with the higher scholarship acquire from 9 to 18 credits more with respect to students with a lower scholarship during the frist year. Considering that the regular number of credits for the first year is 60 and that the average number of credits obtained in the sample is around 32 , the size of the effect is arguably large (from $28 \%$ to $56 \%$ ).

The average of first year grades of those students with higher scholarships is around 2 points higher than the one of those with a lower financing. The grades scale in Italy ranges from 18 (sufficiency grade) to 30 points (plus laude). Since the sample mean of the average first year grade is of about 26 points, the estimated causal effect of an $€ 840$ higher scholarship is of about the $7 \%$ on the average mark.

It is important to notice that, fellowship need not be reimboursed if the credit requirements is achieved. Students aiming at fullfilling this requirement only may pass more exams but with lower grades. I check if this is the case by looking at the effect on students' GPA at the end of the year. Pure credit requirements seem to be sufficient to increase students' performance not only in terms of credit achievement but also with respect to marks. In fact, as shown in the Panel C, an index of performance (made out of an average on normalized credit achievement and average marks) jumps of about 0.1 decimal points for students with the higher scholarship. 
Finally, I analyze the effect on the probability of having satisfy the credits requirements for the maintenance of the scholarship, which are set equal to 25 (30) credits for the undergraduate (master) students. The average rate of success in the sample is of about 78\%, a fairly large fraction. Nevertheless, the results show that the monetary incentives still have a positive effect on the probability of having satisfied this requirement. In fact, the effect goes from a minimum of 0.22 points to a maximum of 0.47 probability points, which is equal to an average percentage effect of $28 \%$ and $60 \%$ respectively. What is clear from the analysis is that the current scholarship design could be further used as an effective instrument for reducing the percentage of "Fuori Corso" students.

It is interest to contrast this overall finding, that the RSS boosts students' achievement, with the results found in Angrist et al. (2009), which instead find no effects on first year grades, of pure monetary incentives in a randomized experiment. A possible explanation of such divergence is that in the Canadian contest, the STAR program consists in subsides on tuition, which do not have the same role of the Right to Study Scholarship. In this sense, the RSS is designed for helping those students who otherwise would not have the means to attend tertiary education and this is a decisive incentive. The students analyzed in Angrist et al (2009) are already enrolled at the time of the experiment in the University.

Moreover, the effect presented above adds a new insight for the Italian empirical literature. Differently from Schizzerotto et al. (2012), who have not found any significant effect of mean-tested fellowships on students' performances, we show that monetary incentives are useful to enhance academic achievement. One reason for this discrepancy might be that since their work use survey data and a relatively small sample to apply a Regression Discontinuity Design, their estimates might not have been precise enough to allow them to find significant results. In addition, Mealli and Rampichini (2012) have found significant effects of the RSS only on drop-out of students enrolled at the Universities of Catania, Milan, Padova and Salerno, without focusing on students achievements. They do not find any significant effect for the lower income students. This is in contrast with the present results which are focused on lower income students.

I proceed with the analysis in Table 5 by looking at the scholarships' effects on the probability 
of obtaining the total number of credits expected for the first year of enrolment at the date of 10 August 2009, which we take as an indicator directly related to the probability to be "Fuori Corso". 9 Although these results have a positive sign (around 0.1 points) and seem to be fairly stable over the different polynomial specifications, they are not significant. Given that the analysis above suggets that the minimum credit requirements may have significant effects on performance (credits, grades and probability of meeting the requirement itself), a possible experimentation for policy would be making such minimum requirements closer to the regular number of credits expected from students along the years (60 credits per year). This could allow the RSS to more effectively serve the purpose of reducing the share of "Fuori Corso" students.

In order to gain more insight on the underlying relationship between the monetary incentives and students performance, I analyze treatments effects on the two thresholds separately. The average increase on the scholarship amount at the first threshold is of around $€ 950$ while the difference at the second threshold is mildly smaller, around $€ 730$. The estimates are reported in Tables 6 and 7.

For the first threshold, I find positive and significant effects for all the outcome variables. For the second threshold instead, results are less clear cut. Treatment effects are only significant on the number of credits and on the probability of having satisfied the maintenance requirements. Considering that the sample size and estimated standard errors are similar around both thresholds, such results suggest that the scholarship is more effective in boosting academic performance of lower income students. Even if we consider that the average increase in grants around the second threshold is about $24 \%$ lower, the decrease in the size of the effect on the number of credits achieved and average grade is fairly lower than that. This interpretation suggests that policy makers could allocate a higher share of funds to the less well-off recipients if the goal is to increase the number of credits and grades.

Finally, I investigate how treatment effects change within sub-groups of population. More specifically, I firstly analyze the results by students status, "Fuori Sede", "In sede" and "Pendolari, and,

\footnotetext{
9 "Fuori Corso" status is assigned when the student do not acquire 60 credits at the $31 / 03 / 2010$.
} 
unfortunately, I do not find any significant and consistent result for our different specifications. The same happens when differentiating for Undergraduate and Master students. This may suggests that the sample is not large enough to allow us to obtain precise enough estimates on these subgroups.

However, I was able to successfully exploit differences in effects between female and male students. Results are reported in the Table 8 and 9, for female and male respectively. I find that the large and significant scholarship effects on credit achievement are mostly driven by male students. Although still positive, these effects for female are smaller and not significant. On the other hand, the previous aggregate results on average grades are mainly driven by female students and they are still positive but not significant for male. These results show that monetary incentives are differently perceived between male and female students, as it is found in previous literature. In the present research, I find pure monetary incentives to be effective in raising the academic performance of both genders, but in a heterogeneous way. For male, the significant effect is on credit achievement, while for female it is on grades.

\section{Robustness}

In order to further assess the validity of our results, I perform a standard graphical analysis both on treatment and pre-treatment variables. Results are reported in Figures 1 and 2. I allow for a 4th order polynomial on both side of the threshold and show a $90 \%$ confidence interval around estimates. As it is possible to see, the graphical analysis confirms the results found with regressions estimates. For all the treatment variables (except for the average for which results is less clear cut), we find a significant and positive jump before the aggregate threshold, meaning that those students just before the threshold, i.e with an higher scholarship, perform better than those just after it, i.e with a lower scholarship.

Since it is impossible to test for the continuity assumption directly, I can test some implications of it. More specifically, all the pre-treatment characteristics should have identical distribution, at the limit, on the two sides of the cutoff. Therefore, in order to test for the validity of our identification strategy, I test for a discontinuity in all of our pre-treatment variables applying the same four 
specifications used for the post-treatment outcomes. I find no significant discontinuity on these in any of these covariates, which is reassuring for the validity of our identification strategy. These results are reported in Table 10.

In Figure 2 I show instead a graphical analysis on these pre-treatment covariates: Sex, Age, High-School Grade, ISPE, Probability to be "Fuori Sede" students. Once more, I find no significant jump in any of the pretreatment variables. Average High-School Grade seems to be higher for those students with the higher scholarship, but, as shown in the regression estimates, this difference is not significant. Moreover, I test further for this possible ability bias by looking at the probability to be "Fuori Sede". In fact, if students with higher High-School Grade, decide to go to college only if they get higher scholarships, I should see a jump in the probability to be "Fuori Sede" since these are those getting higher grants. Estimates show that this is not the case.

A further important issue to the validity of the identification strategy has to do with manipulation of the assigned variable. Since the value of scholarships are based on the tax report of family income (ISEE), there could exist some problems of manipulation. Fortunately, I can test for this hypothesis. First, I test for the continuity of the ISPE (wealth indicator) variable at the threshold, as for other covariates. Second, I perform the McCrary test (2008) on the density of assignment variables around the thresholds. Results are available in Figure 2 and 3. As shown

in the Figure 3, there is no significant discontinuity in the density of the observations around the threshold, supporting therefore the hypothesis of no manipulation on the assignment variable, ISEE.

Concluding, after performing all these robustness tests, we should be confident on the validity of the identification strategy and on the estimates of the Local Average Treatment Effects of the scholarship on students' academic performance.

\section{Conclusions}

This paper has studied the role of monetary incentives in an educational context. In economic theoy, monetary incentives are the standard tool to shape indiviual actions and effort and, nowadays, 
many policy interventions are designed in order to use this principle to influence individual decision making. Recently, more and more attention is dedicated on how financial incentives could serve also to condition students behavior in their academic studies. The present paper, in particular, is focused on a public insistution designed principally to provide fair access and equal opportunity in higher education. As it emerges from the results of this research, the scholarships provided for low-income students, could not only respond to the equity purpose cited above, but they could also be used as active tools to boost students performances. In particular, I found that on average $€ 840$ more will bring students to get from 9 to 18 credits more by the end of the year, with gains also for their GPA, i.e around two points more (the $7 \%$ of the average mark). Moreover, I found that the scholarships are more effective in this purpose for lower income students (first threshols results), suggesting that policy maker who wants to magnify such effect should allocate more and/or higher scholarship for this type of students. In line with the literature, I also find gender gaps. In particular, female students drive the results on the GPA (probably because they acquire already an above average amount of credits) while male students drive the finding on credits. The results presented seem to be valid and robust to different consistency checks as I shown in the robustness section.

With the present paper, I want to add new causal evidence on how financial incentives shape individual actions, particularly in an educational context. I find that pure monetary incentives can significantly increase academic performance in a context of lower income students. Moreover, the aim of this research is also to provide recommendations for policy maker on how to properly design instutions that want to effectively boost academic perfromances. Further research should explain through which channel the financial incentives are working. In particular, is suggested to acquire additional information in order to understand if students are studying better just because of the threath of loosing the scholarship and/or because they have a positive shock on their income, with consequences on their labor supply. Responding to such questions, will allow to better target the scholarship and the related requirements. 


\section{References}

[1] Angrist, Joshua D. and Victor Lavy (1999) "Using Maimonides rule to estimate the effect of class size on scholastic achievment", Quarterly Journal of Economics, May, pp. 533-575.

[2] Angrist, Joshua D. and Victor Lavy (2002), " The Effect of High School Matriculation Awards: Evidence from Randomized Trials", NBER Working Paper No. 9389.

[3] Angrist, Joshua D., Daniel Lang and Philip Oreopoulos (2009), " Incentives and services for college achievement: evidence from a randomized trial" ",American Economic Journal, Vol.1, No.1, pp 136-63.

[4] Bertola, Giuseppe and Daniele Checchi (2003), "Education financing and student achievement", Swiss Review of Education - Revue suisse des sciences de l'éducation, Vol. 25, No. 3, pp 431-54.

[5] Belot, Michele, Erik Canton, and Dinand Webbink (2007) "Does reducing student support affect scholastic performance? Evidence from a Dutch reform". Empirical Economics, Vol. 32 No 2-3 pp. 261-275.

[6] Bound, John, Michael Lovenheim and Sarah Turner (2006), "Understanding the Increased Time to the Baccalaureate Degree", Mimeo, Univesrsity of Michigan.

[7] Bowen, W.G., Chingos M.M. and McPherson M.S. (2009), Crossing the Finish Line: Completing College atAmerica's Public Universities, Princeton University Press, Princeton.

[8] Brunello, G. and Rudolf Winter-Ebmer (2003), "Why do students expect to stay longer in college? Evidence from Europe", Economics Letters, Vol. 80, No. 2, pp. 247-253.

[9] Brunello, G. and Checchi D. (2007), "Does School Tracking Affect Equality of Opportunity? New International Evidence", Economic Policy, 22(52): 783-861.

[10] Checchi, Daniele, (2002), 'Formazione e Percorsi Lavorativi dei laureati dell' Università degli Studi di Milano", Working Paper n. 14.2002, Universit‘a Statale of Milan.

[11] Cornwell, Christopher, Kyung Hee Lee, and David B. Mustard (2003), "The Effects of MeritBased Financial Aid on Course Enrollment, Withdrawal and Completion in College" IZA Discussion Paper. 
[12] Dearden, Lorraine, Carl Emmerson, Christine Frayne, Costas Meghir, Karl Ashworth, Jay Hardman, Yvette Hartfree, Sue Maguire, Sue Middleton and Debbi Smith (2002), "Education Maintenance Allowance: The First Two Years A Quantitative Evaluation", UK Department for Education and Skills Research Report No.352.

[13] De Paola, Maria, Vincenzo Scoppa and Rosanna Nisticò (2012), "Monetary Incentives and Student Achievement in a Depressed Labor Market: Results from a Randomized Experiment," Journal of Human Capital, University of Chicago Press, Vol. 6, No.1, pp 56 - 85.

[14] Dynarski, Susan (2002). "The Behavioral and Distributional Implications of Aid for College." American Economic ReviewVol. 92, No. 2, pp 279-285.

[15] Dynarski, Susan (2003). "Does Aid Matter? Measuring the Effect of Student Aid on College Attendance and Completion." American Economic Review Vol. 93, No. 1, pp 279- 288.

[16] Dynarski, Susan (2005). "Building the Stock of College-Educated Labor." Working paper, Kennedy School, Harvard University.

[17] Garibaldi Pietro, Francesco Giavazzi, Andrea Ichino and Enrico Rettore (2012), "College cost and time to complete a degree: Evidence from tuition discontinuities", The Review of Economics and Statistics, Vol. 94, No.3, pp 699-711.

[18] Groen, Jeffrey, George Jakubson, Ronald G. Ehrenberg, Scott Condie and Albert YungHsu Liu (2006), "Program Design and Student Outcomes in Graduate Education", NBER Working Paper No. 12064.

[19] Hahn, J., Todd P. and van der Klaauw W. (2001), "Identification and Estimation of Treatment Effects with a Regression-Discontinuity Design”, Econometrica Vol.69, No. 1, pp. 201-209.

[20] Häkkinen, I. and Uusitalo R. (2003), "The effect of a student aid reform on graduation: a duration analysis". Journal of Applied Econometrics, 5(1): 1-28.

[21] Hensen, Kari A., and Mack Shelley. 2003. "The Impact of Supplemental Instruction: Results from a large, public, Midwestern University." Journal of College Student Development, Vol. 44, No. 2, pp 250-59.

[22] Hoffer, Thomas B. and Vincent Welch (2006), "Time to Degree of U.S. Research Doctorate Recipients", National Science Foundation, Directorate for Social, Behavioral, and Economic Sciences InfoBrief No. 312. 
[23] Imbens, Guido W. and Joshua D. Angrist (1994), "Identification and Estimation of Local Average Treatment Effects", Econometrica, Vol. 62, No. 2, pp. 467-75.

[24] Kane, Thomas J. (2003), "A Quasi-Experimental Estimate of the Impact of Financial Aid on College-Going", NBER Working Paper No. 9703.

[25] Lavy, V.,Silva, O., Weinhardt F. (2009), "The Good, the Bad and the Average: Evidence on the Scale and Nature of Ability Peer Effects in Schools", NBER Working Paper 15600.

[26] Lee, David S. (2006), "Randomized Experiments from Non-random Selection in U.S. House Elections", Journal of Econometrics,Vol 142, No. 2, pp 675-697.

[27] Leslie, Larry L. and Paul T. Brinkman (1987), "Student Price Response in Higher Education: The Student Demand Studies", Journal of Higher Education, Vol. 58, No. 2, pp. 181-204.

[28] Leuven, Edwin, Hessel Oosterbeek and Bas van der Klaauw (2006), "The effect of financial rewards on students' achievement: Evidence from a randomized experiment", Journal of the European Economic Association Vol 8, No 6, pp 1243-1265.

[29] McCrary, Justin (2007), "Manipulation of the running variable in the regression discontinuity design: a density test", NBER Technical Working Paper No. 334.

[30] McPherson, Michael, and M. Schapiro (2006), "College Access: Opportunity or Privilege?", College Board.

[31] Mealli, Fabrizia and Carla Rampichini (2012), "Evaluating the Effects of University Grants by using Regression Discontinuity Designs" Journal of Royal Statistic Society, Vol 175, No. 3 , pp $775-798$.

[32] OECD (2013), "Education at Glance", Paris.

[33] Sacerdote, Bruce (2001) "Peer Effects with Random Assignment: Results for Dartmouth Roommates", Quarterly Journal of Economics Vol.116, No.2, pp 681-704.

[34] Schizzerotto, Antonio, Loris Vergolini and Nadir Zanini (2012), "Merit-Based Financial Aid to Students From Low-Income Families and its Effects on Academic Performance", Research Institute for the Evaluation of Public Policies - IRVAP.

[35] van der Klaauw, W., (2002), "Estimating the Effect of Financial Aid Offers on College Enrollment:a Regression-Discontinuity Approach", International Economic Review, Vol. 43, No. 4., pp. $1249-1287$. 
[36] Van Ours, J. C. and Ridder G. (2003)."Fast Track or Failure: A Study of the Graduation and Dropout Rates of Ph.D. Students in Economics", Economic of Education Review, 22(2): $157-166$ 


\section{Appendix}

Table 3: Descriptive Statistics

\begin{tabular}{rccccc}
\hline Variables & Obs & Mean & Std. Dev. & Min & Max \\
\hline & & & & & \\
Female & 2430 & 0.6 & 0.48 & 0 & 1 \\
Age & 2430 & 21.44 & 3.53 & 18 & 53 \\
& & & & & \\
Region & & & & & \\
Center & 2430 & 0.01 & 0.11 & 0 & 1 \\
Center - North & 2430 & 0.11 & 0.32 & 0 & 1 \\
Center - South & 2430 & 0.04 & 0.21 & 0 & 1 \\
Foreign & 2430 & 0.06 & 0.24 & 0 & 1 \\
Islands & 2430 & 0.09 & 0.29 & 0 & 1 \\
North & 2430 & 0.37 & 0.48 & 0 & 1 \\
South & 2430 & 0.28 & 0.45 & 0 & 1 \\
& & & & & \\
High School Grade & 2301 & 81.66 & 13.48 & 60 & 100 \\
Credits & 2425 & 30.88 & 16.16 & 0 & 130 \\
Average & 1750 & 26 & 2.83 & 18 & 30 \\
& & & & & \\
In sede & 2430 & 0.4 & 0.49 & 0 & 1 \\
Pendolari & 2430 & 0.12 & 0.32 & 0 & 1 \\
Fuori Sede & 2430 & 0.47 & 0.49 & 0 & 1 \\
\hline Scholarship type & & & & & \\
\hline
\end{tabular}

Note. Statistics for the freshman who enrolled at University of Bologna in the 2008/2009 academic year. 
Table 4: Grant Effects on Students' Achievement

\begin{tabular}{|c|c|c|c|c|}
\hline & $\begin{array}{l}\text { Local Linear } \\
\quad \pm 500\end{array}$ & $\begin{array}{l}\text { Polynom. 2nd } \\
\quad \pm 850\end{array}$ & $\begin{array}{l}\text { Polynom. 3rd } \\
\quad \pm 1200\end{array}$ & $\begin{array}{l}\text { Polynom. 4th } \\
\quad \pm 1400\end{array}$ \\
\hline \multicolumn{5}{|l|}{ Panel A: Credits } \\
\hline Higher Scholarships' Effect & $\begin{array}{l}9.646^{* *} \\
(3.951)\end{array}$ & $\begin{array}{c}10.141^{* *} \\
(4.286)\end{array}$ & $\begin{array}{c}15.320^{* * *} \\
(4.722)\end{array}$ & $\begin{array}{c}18.852^{* * *} \\
(5.356)\end{array}$ \\
\hline Constant & $\begin{array}{c}25.602^{* * * *} \\
(3.224)\end{array}$ & $\begin{array}{c}24.944^{* * * *} \\
(3.329)\end{array}$ & $\begin{array}{c}21.076^{* * *} \\
(3.743)\end{array}$ & $\begin{array}{c}18.280^{* * *} \\
(4.292)\end{array}$ \\
\hline Obs & 312 & 535 & 754 & 865 \\
\hline \multicolumn{5}{|l|}{ Panel B: Average Grade } \\
\hline Higher Scholarships' Effect & $\begin{array}{l}1.867^{* *} \\
(0.846)\end{array}$ & $\begin{array}{l}1.792^{*} \\
(0.940)\end{array}$ & $\begin{array}{l}2.063^{* *} \\
(1.026)\end{array}$ & $\begin{array}{l}1.930^{*} \\
(1.159)\end{array}$ \\
\hline Constant & $\begin{array}{c}25.157^{* * *} \\
(0.709)\end{array}$ & $\begin{array}{c}24.935^{* * *} \\
(0.774)\end{array}$ & $\begin{array}{c}24.764^{* * *} \\
(0.846)\end{array}$ & $\begin{array}{c}24.919^{* * *} \\
(0.956)\end{array}$ \\
\hline \multirow[b]{2}{*}{ Panel C: Performanc } & 232 & 392 & 557 & 641 \\
\hline & & & & \\
\hline Higher Scholarships' Effect & $\begin{array}{l}0.106^{* *} \\
(0.044)\end{array}$ & $\begin{array}{l}0.090^{*} \\
(0.047)\end{array}$ & $\begin{array}{l}0.113^{* *} \\
(0.052)\end{array}$ & $\begin{array}{c}0.127^{* *} \\
(0.061)\end{array}$ \\
\hline Constant & $\begin{array}{c}0.670^{* * *} \\
(0.038)\end{array}$ & $\begin{array}{c}0.674^{* * *} \\
(0.038)\end{array}$ & $\begin{array}{c}0.652^{* * * *} \\
(0.043)\end{array}$ & $\begin{array}{c}0.645^{* * *} \\
(0.051)\end{array}$ \\
\hline Obs & 232 & 392 & 557 & 641 \\
\hline \multicolumn{5}{|c|}{ Panel D: P(Credits'Requirements) } \\
\hline Higher Scholarships' Effect & $\begin{array}{c}0.229^{* *} \\
(0.100)\end{array}$ & $\begin{array}{c}0.262^{* *} \\
(0.114)\end{array}$ & $\begin{array}{c}0.380^{* * * *} \\
(0.129)\end{array}$ & $\begin{array}{c}0.472^{* * * *} \\
(0.149)\end{array}$ \\
\hline Constant & $\begin{array}{c}0.631^{* * *} \\
(0.083)\end{array}$ & $\begin{array}{c}0.603^{* * *} \\
(0.094)\end{array}$ & $\begin{array}{c}0.519^{* * *} \\
(0.106)\end{array}$ & $\begin{array}{c}0.415^{* * *} \\
(0.121)\end{array}$ \\
\hline Obs & 312 & 535 & 754 & 865 \\
\hline
\end{tabular}

Note. OLS estimates of equation:

$$
Z_{i}=\alpha+F\left(Y_{i}\right)+\gamma D_{i}+\epsilon_{i}
$$

where $Z_{i}$ is the vector of outcomes variables (Credits, Average Grade, Performance, $\mathrm{P}$ (Credit Requirements)); $F\left(Y_{i}\right)$ is a vector whose elements are two polynomials (one for each side of the threshold) in the absolute difference between the ISEE declaration and the thresholds ; $D_{i}$ is a dummy taking value 1 for students on the left side of the threshold. Robust standard errors in parentheses. 
Table 5: Grant Effects on "Fuori Corso" proxy

\begin{tabular}{lcccc}
\hline & $\begin{array}{c}\text { Local Linear } \\
\pm 500\end{array}$ & $\begin{array}{c}\text { Polynom. 2nd } \\
\pm 850\end{array}$ & $\begin{array}{c}\text { Polynom. 3rd } \\
\pm 1200\end{array}$ & $\begin{array}{c}\text { Polynom. 4th } \\
\pm 1400\end{array}$ \\
\hline \multicolumn{1}{c}{ Panel D: P(60 Credits) } & & & & \\
Higher Scholarships' Effect & 0.057 & 0.054 & 0.086 & 0.100 \\
& $(0.062)$ & $(0.069)$ & $(0.078)$ & $(0.091)$ \\
Constant & 0.045 & 0.044 & 0.033 & 0.035 \\
& $(0.043)$ & $(0.045)$ & $(0.052)$ & $(0.062)$ \\
R-squared & & & & 0.013 \\
Obs & 0.006 & 0.003 & 0.011 & 865 \\
& 312 & 535 & 754 & \\
\hline
\end{tabular}

Note. OLS estimates of equation:

$$
Z_{i}=\alpha+F\left(Y_{i}\right)+\gamma D_{i}+\epsilon_{i}
$$

where $Z_{i}$ is the outcomes variable $\mathrm{P}$ (Regular Credit Requirements). Credit Requirements is a dummy taking value 1 for students who have completed, at least, 60 credits in the academic year. Robust standard errors in parentheses. 
Table 6: First Threshold Effects

\begin{tabular}{|c|c|c|c|c|}
\hline & $\begin{array}{l}\text { Local Linear } \\
\quad \pm 500\end{array}$ & $\begin{array}{l}\text { Polynom. 2nd } \\
\quad \pm 850\end{array}$ & $\begin{array}{l}\text { Polynom. 3rd } \\
\quad \pm 1200\end{array}$ & $\begin{array}{l}\text { Polynom. 4th } \\
\quad \pm 1400\end{array}$ \\
\hline \multicolumn{5}{|l|}{ Panel A: Credits } \\
\hline First Threshold Effect (950€) & $\begin{array}{c}11.863^{* *} \\
(5.639)\end{array}$ & $\begin{array}{l}11.955^{*} \\
(6.127)\end{array}$ & $\begin{array}{c}18.113^{* * *} \\
(6.884)\end{array}$ & $\begin{array}{c}23.483^{* * *} \\
(8.117)\end{array}$ \\
\hline Constant & $\begin{array}{c}23.245^{* * *} \\
(4.715)\end{array}$ & $\begin{array}{c}22.843^{* * *} \\
(4.787)\end{array}$ & $\begin{array}{c}18.198^{* * *} \\
(5.459)\end{array}$ & $\begin{array}{c}15.648^{* *} \\
(6.411)\end{array}$ \\
\hline Obs & 162 & 273 & 369 & 421 \\
\hline \multicolumn{5}{|l|}{ Panel B: Average Grade } \\
\hline First Threshold Effect (950€) & $\begin{array}{c}3.026^{* * *} \\
(1.044)\end{array}$ & $\begin{array}{c}2.845^{* *} \\
(1.255)\end{array}$ & $\begin{array}{l}2.637^{*} \\
(1.363)\end{array}$ & $\begin{array}{c}2.248 \\
(1.533)\end{array}$ \\
\hline Constant & $\begin{array}{c}24.482^{* * *} \\
(0.826)\end{array}$ & $\begin{array}{c}24.443^{* * *} \\
(1.022)\end{array}$ & $\begin{array}{c}24.537^{* * *} \\
(1.117)\end{array}$ & $\begin{array}{c}24.699^{* * *} \\
(1.275)\end{array}$ \\
\hline \multirow[b]{2}{*}{ Panel C: Performance } & 124 & 204 & 280 & 320 \\
\hline & & & & \\
\hline First Threshold Effect (950€) & $\begin{array}{c}0.186^{* * *} \\
(0.062)\end{array}$ & $\begin{array}{c}0.154^{* *} \\
(0.047)\end{array}$ & $\begin{array}{c}0.175^{* *} \\
(0.077)\end{array}$ & $\begin{array}{c}0.191^{* *} \\
(0.092)\end{array}$ \\
\hline Constant & $\begin{array}{c}0.608^{* * * *} \\
(0.053)\end{array}$ & $\begin{array}{c}0.634^{* * * *} \\
(0.057)\end{array}$ & $\begin{array}{c}0.605^{* * *} \\
(0.064)\end{array}$ & $\begin{array}{c}0.606 * * * \\
(0.076)\end{array}$ \\
\hline Obs & 124 & 204 & 280 & 320 \\
\hline \multicolumn{5}{|c|}{ Panel D: P(Credits'Requirements) } \\
\hline First Threshold Effect (950€) & $\begin{array}{c}0.203 \\
(0.143)\end{array}$ & $\begin{array}{l}0.324^{*} \\
(0.165)\end{array}$ & $\begin{array}{c}0.480^{* * *} \\
(0.184)\end{array}$ & $\begin{array}{c}0.649^{* * *} \\
(0.209)\end{array}$ \\
\hline Constant & $\begin{array}{c}0.652^{* * *} \\
(0.119)\end{array}$ & $\begin{array}{c}0.521^{* * * *} \\
(0.135)\end{array}$ & $\begin{array}{c}0.521^{* * * *} \\
(0.148)\end{array}$ & $\begin{array}{c}0.255 \\
(0.160)\end{array}$ \\
\hline Obs & 162 & 273 & 369 & 421 \\
\hline
\end{tabular}

Note. OLS estimates of equation:

$$
Z_{i}=\alpha+F\left(Y_{i}\right)+\gamma D_{i}+\epsilon_{i}
$$

where $Z_{i}$ is the vector of outcomes variables (Credits, Average Grade, Performance, $\mathrm{P}$ (Credit Requirements)); $F\left(Y_{i}\right)$ is a vector whose elements are two polynomials (one for each side of the threshold) in the absolute difference between the ISEE declaration and the thresholds ; $D_{i}$ is a dummy taking value 1 for students on the left side of the threshold. Robust standard errors in parentheses. 
Table 7: Second Threshold Effect

\begin{tabular}{|c|c|c|c|c|}
\hline & $\begin{array}{l}\text { Local Linear } \\
\quad \pm 500\end{array}$ & $\begin{array}{l}\text { Polynom. 2nd } \\
\quad \pm 850\end{array}$ & $\begin{array}{l}\text { Polynom. 3rd } \\
\quad \pm 1200\end{array}$ & $\begin{array}{l}\text { Polynom. 4th } \\
\quad \pm 1400\end{array}$ \\
\hline \multicolumn{5}{|l|}{ Panel A: Credits } \\
\hline Second Threshold Effect (730€) & $\begin{array}{c}7.093 \\
(5.504)\end{array}$ & $\begin{array}{c}8.989 \\
(6.130)\end{array}$ & $\begin{array}{c}13.296^{* *} \\
(6.612)\end{array}$ & $\begin{array}{c}15.193^{* *} \\
(7.249)\end{array}$ \\
\hline Constant & $\begin{array}{c}28.177^{* * * *} \\
(4.305)\end{array}$ & $\begin{array}{c}26.520^{* * *} \\
(4.777)\end{array}$ & $\begin{array}{c}23.642^{* * *} \\
(5.260)\end{array}$ & $\begin{array}{c}20.691^{* * *} \\
(5.942)\end{array}$ \\
\hline Obs & 150 & 262 & 385 & 444 \\
\hline \multicolumn{5}{|l|}{ Panel B: Grades'Average } \\
\hline Second Threshold Effect (730€) & $\begin{array}{c}0.448 \\
(1.370)\end{array}$ & $\begin{array}{c}0.530 \\
(1.424)\end{array}$ & $\begin{array}{c}1.169 \\
(1.520)\end{array}$ & $\begin{array}{c}1.323 \\
(1.685)\end{array}$ \\
\hline Constant & $\begin{array}{c}26.020^{* * *} \\
(1.203)\end{array}$ & $\begin{array}{c}25.471^{* * * *} \\
(1.221)\end{array}$ & $\begin{array}{c}25.018^{* * *} \\
(1.285)\end{array}$ & $\begin{array}{c}25.193^{* * *} \\
(1.390)\end{array}$ \\
\hline Obs & 108 & 188 & 277 & 321 \\
\hline \multicolumn{5}{|l|}{ Panel C: Performance } \\
\hline Second Threshold Effect (730€) & $\begin{array}{c}0.000 \\
(0.056)\end{array}$ & $\begin{array}{c}0.011 \\
(0.059)\end{array}$ & $\begin{array}{c}0.036 \\
(0.063)\end{array}$ & $\begin{array}{c}0.047 \\
(0.069)\end{array}$ \\
\hline Constant & $\begin{array}{c}0.753^{* * *} \\
(0.044)\end{array}$ & $\begin{array}{c}0.724^{* * *} \\
(0.047)\end{array}$ & $\begin{array}{c}0.711^{* * *} \\
(0.050)\end{array}$ & $\begin{array}{c}0.695^{* * *} \\
(0.054)\end{array}$ \\
\hline Obs & 108 & 188 & 277 & 321 \\
\hline \multicolumn{5}{|l|}{ Panel D: P(Credits'Requirements) } \\
\hline Second Threshold Effect (730€) & $\begin{array}{l}0.248^{*} \\
(0.140)\end{array}$ & $\begin{array}{c}0.241 \\
(0.157)\end{array}$ & $\begin{array}{l}0.307^{*} \\
(0.179)\end{array}$ & $\begin{array}{c}0.323 \\
(0.209)\end{array}$ \\
\hline Constant & $\begin{array}{c}0.610^{* * *} \\
(0.117)\end{array}$ & $\begin{array}{c}0.650^{* * *} \\
(0.129)\end{array}$ & $\begin{array}{c}0.602^{* * *} \\
(0.150)\end{array}$ & $\begin{array}{c}0.561^{* * *} \\
(0.177)\end{array}$ \\
\hline Obs & 150 & 262 & 385 & 444 \\
\hline
\end{tabular}

Note. OLS estimates of equation:

$$
Z_{i}=\alpha+F\left(Y_{i}\right)+\gamma D_{i}+\epsilon_{i}
$$

where $Z_{i}$ is the vector of outcomes variables (Credits, Average Grade, Performance, $\mathrm{P}$ (Credits' Requirements)); $F\left(Y_{i}\right)$ is a vector whose elements are two polynomials (one for each side of the threshold) in the absolute difference between the ISEE declaration and the thresholds; $D_{i}$ is a dummy taking value 1 for students on the left side of the threshold. Robust standard errors in parentheses. 
Table 8: Female Estimates

Local Linear Polynom. 2nd Polynom. 3rd Polynom. 4th $\begin{array}{llll} \pm 500 & \pm 850 & \pm 1200 & \pm 1400\end{array}$

Panel A: Credits

(a) Females

Higher Scholarships' Effect

$\begin{array}{cc}5.186 & 2.876 \\ (4.65) & (5.01) \\ 30.845^{* * *} & 33.134^{* * *} \\ (3.91) & (4.00) \\ 206 & 340\end{array}$

6.019
$(5.46)$
$29.954^{* * *}$
-4.43
472

5.217

Constant

$30.845^{* * *}$

Obs

$(3.91)$

$(4.00)$

472

$30.872^{* * *}$

$-4.99$

537

\begin{tabular}{|c|c|c|c|c|}
\hline \multicolumn{5}{|l|}{ Panel B: Average Grade } \\
\hline Higher Scholarships' Effect & $\begin{array}{c}2.320^{* *} \\
(0.94)\end{array}$ & $\begin{array}{c}2.156^{* *} \\
(1.04)\end{array}$ & $\begin{array}{c}2.540^{* *} \\
(1.14)\end{array}$ & $\begin{array}{l}1.73 \\
(1.2)\end{array}$ \\
\hline Constant & $\begin{array}{c}25.189^{* * * *} \\
(0.82)\end{array}$ & $\begin{array}{c}25.100^{* * * *} \\
(0.89)\end{array}$ & $\begin{array}{c}24.943^{* * *} \\
(0.96)\end{array}$ & $\begin{array}{c}25.777^{* * *} \\
(0.97)\end{array}$ \\
\hline Obs & 161 & 266 & 369 & 418 \\
\hline \multicolumn{5}{|l|}{ Panel C: Performance } \\
\hline Higher Scholarships' Effect & $\begin{array}{c}0.107^{* *} \\
(0.05)\end{array}$ & $\begin{array}{l}0.076 \\
(0.05)\end{array}$ & $\begin{array}{c}0.102^{*} \\
(0.06)\end{array}$ & $\begin{array}{l}0.086 \\
(0.07)\end{array}$ \\
\hline Constant & $\begin{array}{c}0.666^{* * *} \\
(0.04)\end{array}$ & $\begin{array}{c}0.689^{* * *} \\
(0.05)\end{array}$ & $\begin{array}{c}0.666^{* * *} \\
(0.05)\end{array}$ & $\begin{array}{c}0.683^{* * *} \\
(0.06)\end{array}$ \\
\hline Obs & 161 & 266 & 369 & 418 \\
\hline \multicolumn{5}{|c|}{ Panel D: P(Credits'Requirements) } \\
\hline Higher Scholarships' Effect & $\begin{array}{l}0.132 \\
(0.12)\end{array}$ & $\begin{array}{c}0.13 \\
(0.14)\end{array}$ & $\begin{array}{c}0.24 \\
(0.16)\end{array}$ & $\begin{array}{c}0.249 \\
(0.2)\end{array}$ \\
\hline Constant & $\begin{array}{l}0.746^{* * *} \\
(0.1)\end{array}$ & $\begin{array}{l}0.750^{* * *} \\
(0.11)\end{array}$ & $\begin{array}{l}0.639^{* * *} \\
(0.13)\end{array}$ & $\begin{array}{l}0.607^{\text {**** }} \\
(0.16)\end{array}$ \\
\hline Obs & 206 & 340 & 472 & 537 \\
\hline
\end{tabular}

Note: The reported results on outcome variables are only for female scholarship recipients enrolled at University of Bologna. OLS estimates of equation:

$$
Z_{i}=\alpha+F\left(Y_{i}\right)+\gamma D_{i}+\epsilon_{i}
$$

where $Z_{i}$ is the vector of outcomes variables (Credits, Average Grade, Performance, $\mathrm{P}$ (Credits' Requirements)); $F\left(Y_{i}\right)$ is a vector whose elements are two polynomials (one for each side of the threshold) in the absolute difference between the ISEE declaration and the thresholds ; $D_{i}$ is a dummy taking value 1 for students on the left side of the threshold. Robust standard errors in parentheses. 
Table 9: Male Estimates

Local Linear Polynom. 2nd Polynom. 3rd Polynom. 4th $\begin{array}{llll} \pm 500 & \pm 850 & \pm 1200 & \pm 1400\end{array}$

Panel A: Credits

(a) Males

$\begin{array}{lcccc}\text { Higher Scholarship Effect } & 17.630^{* * *} & 19.713^{* * *} & 28.452^{* * *} & 35.753^{* * *} \\ \text { Constant } & (6.36) & (7.01) & (7.43) & (8.16) \\ & 16.442^{* * *} & 14.173^{* * *} & 9.702^{* *} & 3.427 \\ \text { Obs } & (4.46) & (4.52) & (4.86) & (5.07) \\ & 106 & 195 & 282 & 328\end{array}$

Panel B: Average Grade

Higher Scholarship Effect

0.896

1.246

1.435

2.899

$(1.8)$

$(1.91)$

$(2.12)$

(2.71)

Constant

$25.147^{* * *}$

$24.388 * * *$

$24.267^{* * *}$

$22.632^{* * *}$

(1.47)

(1.51)

(1.72)

Obs

71

126

188

(2.35)

223

Panel C: Performance

$\begin{array}{lcccc}\text { Higher Scholarship Effect } & 0.09 & 0.127 & 0.159 & 0.244^{*} \\ \text { Constant } & (0.08) & (0.09) & (0.1) & (0.13) \\ & 0.691^{* * *} & 0.632^{* * *} & 0.615^{* * *} & 0.532^{* * *} \\ \text { Obs } & (0.07) & (0.07) & (0.08) & (0.1) \\ & 71 & 126 & 188 & 223\end{array}$

Panel D: P(Credits'Requirements)

Higher Scholarships' Effect

$0.386^{* *}$

$0.450^{* *}$

$0.592^{* * *}$

$0.751^{* * *}$

Constant

(0.17)

(0.18)

$(0.19)$

$(0.19)$

$0.451^{* * *}$

$0.405^{* * *}$

$0.360 * *$

0.197

(0.15)

(0.14)

(0.16)

(0.16)

Obs

106

195

282

328

Note: The reported results on outcome variables are for male scholarship recipients enrolled at University of Bologna. OLS estimates of equation:

$$
Z_{i}=\alpha+F\left(Y_{i}\right)+\gamma D_{i}+\epsilon_{i}
$$

where $Z_{i}$ is the vector of outcomes variables (Credits, Average Grade, Performance, $\mathrm{P}$ (Credits' Requirements)); $F\left(Y_{i}\right)$ is a vector whose elements are two polynomials (one for each side of the threshold) in the absolute difference between the ISEE declaration and the thresholds ; $D_{i}$ is a dummy taking value 1 for students on the left side of the threshold. Robust standard errors in parentheses. 
Table 10: Regressions on Pre-treatment variables

\begin{tabular}{|c|c|c|c|c|}
\hline & $\begin{array}{l}\text { Local Linear } \\
\quad \pm 500\end{array}$ & $\begin{array}{l}\text { Polynom. 2nd } \\
\quad \pm 850\end{array}$ & $\begin{array}{l}\text { Polynom. 3rd } \\
\quad \pm 1200\end{array}$ & $\begin{array}{l}\text { Polynom. 4th } \\
\quad \pm 1400\end{array}$ \\
\hline Panel A: Sex & & & & \\
\hline Higher Scholarship Effect & $\begin{array}{l}0.032 \\
(0.11)\end{array}$ & $\begin{array}{l}0.006 \\
(0.13)\end{array}$ & $\begin{array}{l}0.001 \\
(0.14)\end{array}$ & $\begin{array}{l}0.163 \\
(0.17)\end{array}$ \\
\hline Constant & $\begin{array}{c}0.545^{* * *} \\
(0.08)\end{array}$ & $\begin{array}{c}0.568^{* * *} \\
(0.10)\end{array}$ & $\begin{array}{c}0.557^{* * *} \\
(0.11)\end{array}$ & $\begin{array}{c}0.469^{* * *} \\
(0.13)\end{array}$ \\
\hline Obs & 321 & 552 & 780 & 899 \\
\hline \multirow{2}{*}{$\begin{array}{c}\text { Panel B: Age } \\
\text { Higher Scholarship Effect }\end{array}$} & & & & \\
\hline & $\begin{array}{l}0.999 \\
(0.71)\end{array}$ & $\begin{array}{l}0.911 \\
(0.81)\end{array}$ & $\begin{array}{l}0.449 \\
(0.97)\end{array}$ & $\begin{array}{l}-0.412 \\
(1.15)\end{array}$ \\
\hline Constant & $\begin{array}{c}21.441^{* * *} \\
(0.47)\end{array}$ & $\begin{array}{c}21.497^{* * *} \\
(0.54)\end{array}$ & $\begin{array}{c}21.785^{* * *} \\
(0.65)\end{array}$ & $\begin{array}{c}22.494^{* * *} \\
(0.80)\end{array}$ \\
\hline Obs & 321 & 552 & 780 & 899 \\
\hline \multicolumn{5}{|l|}{ Panel C: High-School Grade } \\
\hline Higher Scholarship Effect & $\begin{array}{l}4.699 \\
(3.44)\end{array}$ & $\begin{array}{l}6.291 \\
(3.88)\end{array}$ & $\begin{array}{l}6.313 \\
(4.41)\end{array}$ & $\begin{array}{l}8.413 \\
(5.17)\end{array}$ \\
\hline Constant & $\begin{array}{c}80.935^{* * *} \\
(2.57)\end{array}$ & $\begin{array}{c}79.648^{* * *} \\
(2.87)\end{array}$ & $\begin{array}{c}78.287^{* * *} \\
(3.29)\end{array}$ & $\begin{array}{c}76.720^{* * *} \\
(3.89)\end{array}$ \\
\hline Obs & 296 & 510 & 725 & 836 \\
\hline \multicolumn{5}{|l|}{ Panel D: ISPE } \\
\hline Higher Scholarship Effect & $\begin{array}{l}1536.229 \\
(2607.57)\end{array}$ & $\begin{array}{l}2029.465 \\
(3033.52)\end{array}$ & $\begin{array}{l}1445.873 \\
(3415.19)\end{array}$ & $\begin{array}{l}3657.112 \\
(4043.05)\end{array}$ \\
\hline Constant & $\begin{array}{c}10063.320^{* * *} \\
(1855.30)\end{array}$ & $\begin{array}{c}10864.235^{* * *} \\
(2142.27)\end{array}$ & $\begin{array}{c}11198.737^{* * *} \\
(2480.20)\end{array}$ & $\begin{array}{c}10595.645^{* * *} \\
(2968.13)\end{array}$ \\
\hline Obs & 321 & 552 & 780 & 899 \\
\hline \multicolumn{5}{|l|}{ Panel E: P(Fuori Sede) } \\
\hline Higher Scholarship Effect & $\begin{array}{l}0.049 \\
(0.11)\end{array}$ & $\begin{array}{l}0.072 \\
(0.13)\end{array}$ & $\begin{array}{l}0.096 \\
(0.15)\end{array}$ & $\begin{array}{l}0.024 \\
(0.17)\end{array}$ \\
\hline Constant & $\begin{array}{c}0.411^{* * *} \\
(0.08)\end{array}$ & $\begin{array}{c}0.367^{* * *} \\
(0.10)\end{array}$ & $\begin{array}{c}0.349^{* * *} \\
(0.11)\end{array}$ & $\begin{array}{c}0.408^{* * *} \\
(0.13)\end{array}$ \\
\hline Obs & 321 & 552 & 780 & 899 \\
\hline
\end{tabular}

Note. OLS estimates of equation:

$$
V_{i}=\alpha+F\left(Y_{i}\right)+\gamma D_{i}+\epsilon_{i}
$$

where $V_{i}$ is the vector of pre-treatment variables (Sex, Age, High-School Grade, ISPE, P(Fuori Sede)); $F\left(Y_{i}\right.$ ) is a vector whose elements are two polynomials (one for each side of the threshold) in the absolute difference between the ISEE declaration and the thresholds ; $D_{i}$ is a dummy taking value 1 for students on the left side of the threshold. Robust standard errors in parentheses. 


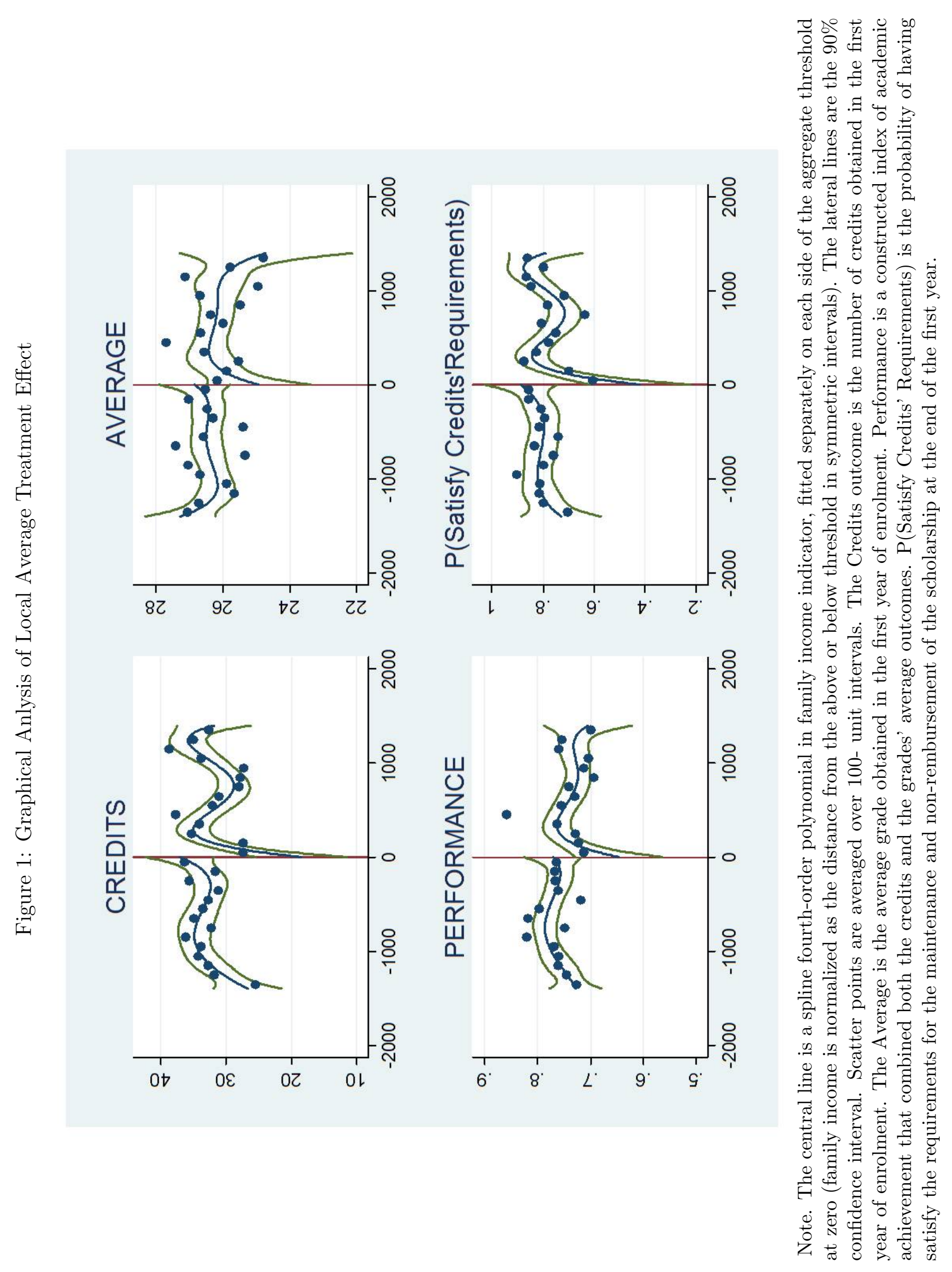



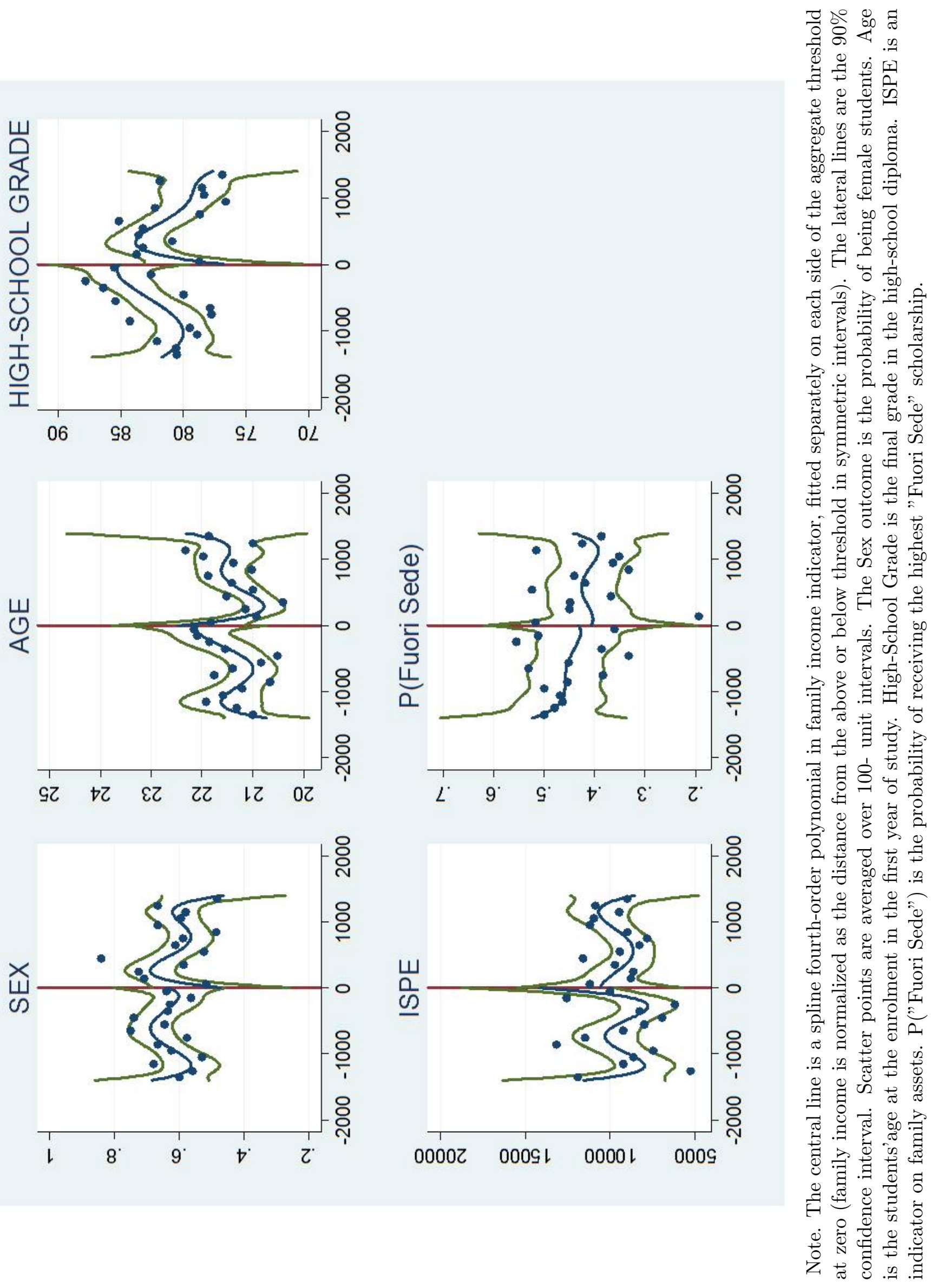

$\dot{\mathrm{i}}$

苟 
Figure 3: Test on Manipulation

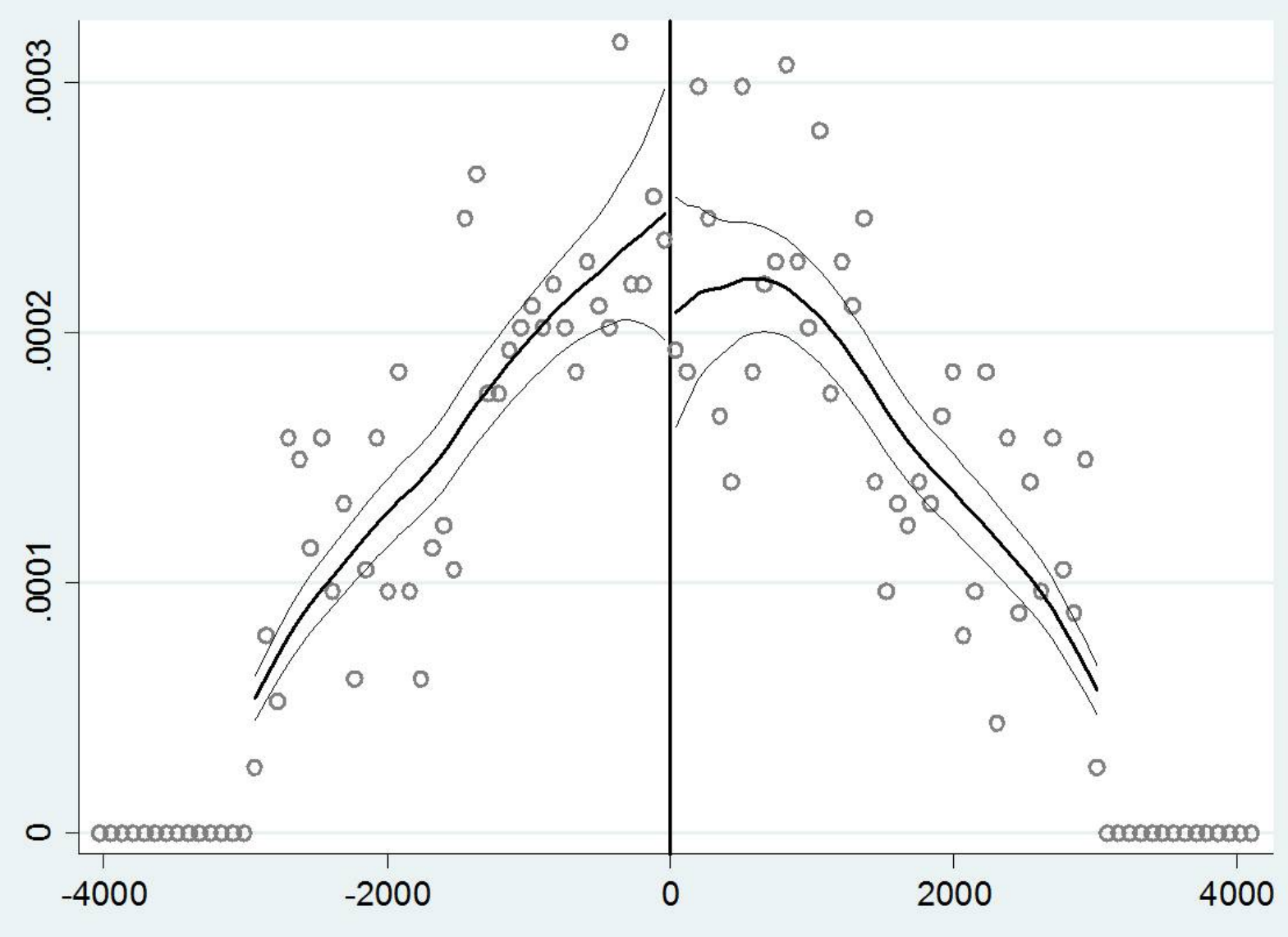

Note.Scatter points of density of observations around the aggregate threshold. The lateral lines are the $95 \%$ confidence interval. 


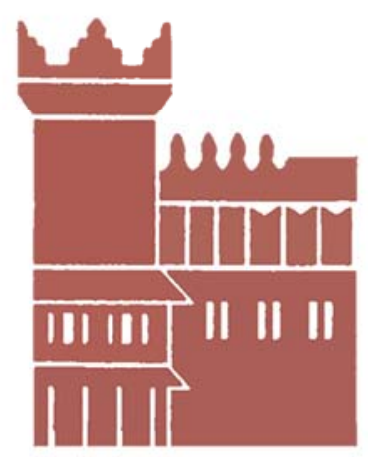

Alma Mater Studiorum - Università di Bologna DEPARTMENT OF ECONOMICS

Strada Maggiore 45

40125 Bologna - Italy

Tel. +39051 2092604

Fax +390512092664

http://www.dse.unibo.it 